\title{
An Exploration Of Gender And Trust In Mentoring Relationships
}

Catherine Elliott, (Email: elliott.young@sympatico.ca), University of Ottawa, Canada Joanne D. Leck, (Email: leck@management.uottawa.ca), University of Ottawa, Canada Barbara Orser, (Email: orser@management.uottawa.ca), University of Ottawa, Canada Catherine Mossop, (Email: www.sagementors.com), Sage Mentors Inc.

\begin{abstract}
To explore the role of gender and trust in mentoring, fifteen interviews with mentors were conducted. Eight mentors were male and seven were female; eight were involved in cross-gender mentoring. Subjects were asked to discuss the levels of trust they had developed in their relationships, and what had influenced its development. Interviews were conducted by telephone, transcribed, and analyzed independently by the two authors. This paper will present these findings and discuss future avenues of research. Practical implications to mentoring program designers are also discussed.
\end{abstract}

\section{INTRODUCTION}

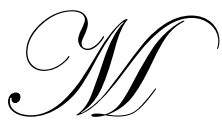

uch research has demonstrated that women are disproportionately represented in upper management and in positions of power, and that the 'glass ceiling' remains intact (Burke, 2002; Jacobs, 1999; Leck, 2002; Shein, Vueller, Lituchy and Liu, 1996). Recent figures show that although women represent 46.6 percent of Canada's workforce and hold 36.6 percent of all management positions, only 7.1 percent occupy the highest positions among Canada's 500 largest organizations (Statistics Canada, 2004). Further, only 14.4 percent of corporate officer positions are held by women in the FP500 (2004 Catalyst Census of Women Corporate Officers and Top Earners of Canada).

One explanation of this gender disparity is the difficulty women face in developing and maintaining an effective mentoring relationship (Ragins, 1989). Schein et al. (1996) argue that mentoring, while important for men, may be indispensable for women. Mentoring enables women to overcome career obstacles, gain information and insight, seize power, understand organizational politics, obtain feedback and gain access to resources (Burke \& McKeen 1990; Collins, 1983; Headlam-Wells, 2004; Lineham \& Walsh, 1999; Ragins, 1996; Ragins and Cotton, 1999). A recent meta-analysis examining the career benefits associated with mentoring found that protégés who have been mentored report greater career outcomes, (specifically compensation and number of promotions), than those who have not been mentored (Allen, Poteet, Eby, Lentz and Lima, 2004). Further, protégés are more likely to be satisfied with their careers, more likely to believe that they would advance in their careers, and more committed to their careers than their non-mentored counterparts. Mentors provide protégés with psychosocial support, such as friendship and acceptance (Kram, 1983, 1985). Mentoring also offers the protégé career development support, such as helping the protégé advance in the organization, providing sponsorship and coaching, setting up challenging assignments, fostering positive visibility, and protecting the protégé from adverse forces (Kram, 1983, 1985).

Previous research has suggested that it is better for female protégés to be mentored by women. For instance, Cooper and Hingley (1983) argued that women need female mentors who can act as role models because female protégés may find it difficult to mirror the 'male behaviors' exhibited by male mentors. Women with female mentors report greater interpersonal comfort than do women with male mentors (Allen, Day and Lentz, 2005; Macoby, 1990). Women with female mentors also receive more psychosocial support and career-development support than do women with male mentors (see Ragins and McFarlin, 1990; Scandura and Williams, 2001; Thomas, 1990). 
Despite the benefits to same-gender mentoring, the low number of women in upper management positions coupled with the fact that the few available female mentors are already overloaded with female protégés means that women are less likely to engage in same-gender mentoring than their male counterparts (Burke, 2002; Burke and McKeen, 1990; Ragins, 1989). As a consequence, aspiring young women must establish successful mentoring relationships with male mentors. This presents a significant barrier to women because women are faced with the challenge of initiating a relationship with a member of the opposite sex (Ragins, 1996). Cross-gender relationship initiation can be misconstrued as a sexual advance and members of the opposite sex are reluctant to initiate relationships in a work setting. Male mentors and female protégés may be reluctant to enter cross-gender mentoring relationships to avoid office gossip, perceived sexual involvement, accusations of sexual harassment, discrediting innuendoes, jealous spouses and resentful co-workers (Bowen, 1985; Fitt and Newton, 1981; Hurley, 1996). Women also may be reluctant to approach male mentors as this may be perceived as 'overly aggressive' and defying traditional gender-role expectations where women take on more passive roles (Ragins, 1996). Finally, many have argued that women have fewer informal and formal opportunities to access potential mentors (Kram, 1985; Lunding, Clements and Perkins, 1978; Ragins, 1996). On an informal level, women may have fewer opportunities to access places frequented by men (e.g., golf games); on a formal level, women may have less access to important projects because women frequently occupy less important and visible roles in the organization.

Once the initial hurdle of initiating a mentoring relationship with a male mentor is jumped, female protégés are faced with other challenges. Research has found that gender-role stereotypes can either consciously or unconsciously cause male mentors to assume that their female protégés lack the skills to grasp complex problems; further, when women do succeed, it is frequently attributed more to luck than competency (Deux and Emswiller, 1974; Noe, 1988). Different socialization practices also cause dysfunction in the mentoring relationship: female protégés are socialized to use relationship practices (e.g., dependency, nurturing, accommodation), while male mentors are frequently over-protective and paternalistic (Kram, 1983; Noe, 1988).

\section{Mentoring And Trust}

The importance of trust has been noted in many management functions, such as leadership, performance appraisal, labor-management relations and self-managed work teams (Mayer, Davis and Schoorman, 1995). Further, Mayer et al. (1995) argue that current trends in demographics and changing management styles suggest that the importance of trust in organizational relationships is likely to increase. However, the role of trust in mentoring relationships has been under-investigated to date. This seems somewhat surprising, given the critical nature of trust in interpersonal relationships and the significance of mentoring as a key developmental relationship for women. For example, it seems evident that male mentors must trust their female protégés in order to sponsor them or select them for important projects or promotions. Similarly, female protégés must trust their male mentors if they are going to listen to and respect their mentors' advice and guidance. Trust in cross-gender mentoring relationships is crucial if women are to be provided with the opportunities to finally break the glass ceiling.

To explore the nature of trust in cross-gender mentoring relationships, a qualitative research design was deemed to be most suitable, to gather "thick, rich description" about mentors' experiences through in-depth interviewing (Geertz, 1973). Mentors were selected as the focus of the study, as numerous authors have pointed out the lack of research conducted from this perspective (Allen and Eby, 2004; Feldman, 1999; Allen and Eby, 2002). Kram, in her pioneering work on mentoring, cautioned researchers not to forget the mentor's perspective (1985); and Feldman observed that the mentor has been, until recently, a "missing person" in the mentoring literature (Feldman, 1999; Allen and Eby, 2004). Particularly in the cross-sex mentoring research, little has been said about the mentor's viewpoint.

\section{METHODOLOGY}

\section{Sample And Context}

The sample for this study was obtained from a program called The Mentoring Partnership, which operates in the Greater Toronto Area (GTA), in the province of Ontario, Canada. The Mentoring Partnership is an alliance of 
community organizations, the Toronto Region Immigrant Employment Council (TRIEC) and corporate partners, who have come together to offer mentoring opportunities for skilled immigrants in the Toronto area. Through this program, the Mentoring Partnership provides career support and guidance for new Canadians who are seeking work in their areas of expertise. With the help of its corporate partners, TRIEC recruits experienced professionals (mentors) who are matched with internationally educated professionals (protégés). Before joining the program, protégés are assessed to ensure that they are "job-ready" (e.g., they possess acceptable language skills, recognized credentials, and a current professional resume). Both mentors and protégés participate in an orientation program which prepares them for their respective roles. They are then introduced and together, they identify the specific objectives of their relationship and the logistics associated with regular communication (e.g., mode of communication - telephone, email, in person - and schedule). The minimum expectation is 24 hours of mentoring contact over a four-month period.

After five months of operation, (May, 2005), the Mentoring Partnership conducted an on-line satisfaction survey, to assess the program's effectiveness. Both mentors and protégés reported on their perceptions of quality and satisfaction with regards to career and psychosocial mentorship functions and program support. They also provided basic demographic, education, and employment information. Of the 110 participants who received the questionnaire, 87 useable responses were received, 48 mentors and 39 protégés. The majority of participants were male: $65.2 \%$ of mentors and $70 \%$ of protégés. Not surprisingly, the level of education was high among both groups: $84 \%$ of mentors and $81 \%$ of protégés reported a Bachelors degree or higher.

As part of the questionnaire, participants were also asked if they would be willing to participate in a followup interview. Twenty-four individuals volunteered: fifteen mentors and nine protégés. Since the objective of this study was to learn more about the mentor's perspective, the fifteen mentors were selected as the sample.

\section{Research Design}

To study this phenomenon, a "basic interpretive" approach was chosen, employing in-depth, semi-structured interviewing to gather data. Following Merriam (2002), this research strategy enables the researcher to better "understand how participants make meaning of a situation or phenomenon"; it is inductive in nature (i.e., it builds toward theory as opposed to testing hypotheses), and it provides a rich, descriptive account of the findings (p. 6-7). Furthermore, a basic interpretive qualitative approach is well-suited to studying a phenomenon which has not been adequately explained by existing theory (Merriam 2002). The authors therefore decided that this study met these criteria - it is exploratory in nature; established theory ${ }^{1}$ does not exist; and furthermore, much of the mentoring and trust research that has been conducted to date has gathered quantitative data.

\section{Procedure}

Fifteen telephone interviews were conducted with mentors who had volunteered from the Mentoring Partnership ${ }^{2}$. Eight of the mentors were male and of these eight, four mentored women. The remaining seven mentors were female; three mentored women (refer to Table 1). The interview opened with general questions about the mentoring relationship - duration, frequency of meeting times, and perceived roles. Subjects were then asked to discuss the nature of trust development in their relationship: whether they had developed trust and how it had developed or failed to develop. Mentors were encouraged to discuss specific events, actions and behaviors that caused the level of trust to change during their relationships, and to explain why they believed the change had occurred. If change did not occur, subjects were asked to provide explanations as well. Interviews were taped, transcribed, and analyzed independently by the two authors. Both authors coded the data according to common themes which emerged. Comparisons were made between the four groups: two cross-gender pairs and two same gender pairs. The two authors then discussed their separate analyses and reached a final interpretation. The findings are discussed below.

\footnotetext{
${ }^{1}$ There are several theoretical models of trust (see Mayer et al., 1995 and McAllister, 1995), however, they have not been tested specifically for mentoring relationships; nor do they specifically account for gender. The mentoring literature has also proposed several theories, however, they do not fully account for the mentor's perspective or for implications of gender.

${ }^{2}$ Protégé interviews are also being conducted and the results will be reported at a later date. Please note that these were not mentor-protégé dyads, however, so no comparisons may be drawn directly between pairs.
} 
Table 1: Gender Of Mentors And Protégés

\begin{tabular}{|l|l|c|c|}
\hline \multirow{3}{*}{ Gender of Mentor } & \multicolumn{3}{|c|}{ Gender of Protégé } \\
\cline { 2 - 4 } & & Female & Male \\
\cline { 2 - 4 } & Female & 3 & 4 \\
\cline { 2 - 4 } & Male & $\mathbf{4}$ & 4 \\
\hline
\end{tabular}

\section{DISCUSSION OF RESULTS}

On average, the duration of the mentoring relationships was 3.3 months. More than half of the interviewees had met, in person, with their protégés every week (57\%). Another $29 \%$ met every other week, and $14 \%$ (2 interviewees) met personally only once or twice. One of these mentors attributed the infrequency of their face-to-face contact to geographic challenges (physically not being able to get together); and both of these mentors, after a lengthy initial meeting, continued to develop their relationships by telephone and email. Almost all of the mentors reported spending a "concentrated" amount of time at the beginning of the relationship in order to get to know their protégés. Typically, the meetings then became less frequent over time and usually shorter in duration. Many transitioned to different media - from personal contact to communication by telephone and email.

Once information was gathered about the characteristics of their relationships, the mentors were asked about the nature of trust development. First, they were asked whether they felt that they had developed trust in their relationship. Then they were asked to elaborate upon their response, and discuss why they felt that they had or had not developed trust and whether any critical incidents had impacted their levels of trust throughout the relationship. To assess these responses, two independent authors coded the mentors' text, according to common themes which emerged (those most frequently mentioned). These themes are reported within the four mentoring groups of interest: male/female, female/male, (cross-gender); and male/male and female/female (same gender). These findings are then situated within the existing mentoring literature, included as a brief discussion within each section. (Refer to Table 2 for a summary of the initial responses. This table is organized by cross-gender and same gender groupings.)

\section{Mentors in Cross-Gender Relationships}

\section{Male Mentor/Female Protégé:}

- $\quad$ Mentoring as an Exchange Relationship

Of the four male mentors in cross-gender relationships, only one unequivocally stated "yes" to the original question, "Do you feel that you developed trust in the relationship?" The other three mentors qualified their answers, emphasizing the transactional nature of the relationship. One claimed that he had "enough" trust for this type of mentoring arrangement and another admitted that he was hesitant to trust $100 \%$ due to the fact that his protégé hadn't earned her trust. Both emphasized the exchange nature of the relationship. As well, there was little mention of the emotional, interpersonal aspect of the relationship; the language was primarily business-like and rational: "feelings" weren't addressed. For example, when the mentors were asked if any critical incidents impacted their level of trust, they all emphasized the "professional" nature of their relationships:

No, she was perfectly respectable and accepting from day one...it was a good relationship.

I was pretty straightforward with her from the outset, and that continued.

I don't think that there was a change in trust. I took it at a very professional level. I know for sure that it has increased but it wasn't a huge increase...gradual.

Based upon some of the documented challenges with males mentoring females, these responses could be expressions, by the male mentors, of mild discomfort with their cross-gender mentoring role: a concerted effort to 
"keep it on a professional level", to ensure that their interests are not misconstrued. According to Kram (1985), in her seminal work on mentoring, many men in cross-gender mentoring relationships are inclined to assume a stereotypical masculine role, (she refers to this as collusion), in order to reduce the ambiguity of working with members of the opposite sex. In one such role, she describes how male mentors see themselves as the "strong warrior" who need to teach their gentler female protégés the hard, rational skills of business. There was evidence of this phenomenon in one mentor's comments: "Yes, we had trust - I was pretty tough with her...She took my advice and followed it." These comments indicate he was "testing" his protégé in order for her to earn his trust; essentially, his level of trust was dependent upon observed behaviors (whether she followed his advice). Furthermore, he placed importance on her ability to demonstrate competence, by developing traditionally "masculine" skills (toughness) to be successful in the workplace.

\section{- $\quad$ Emphasis on Career Advice}

Another related theme which emerged from the male mentor interviews was the focus on career. Given that career mentoring was the main objective of the Mentoring Partnership - to assist/support protégés in their search for career-related employment - these results are not surprising, at first glance. However, what is illuminating is how male mentors provided career mentoring, (the points of emphasis and the points of omission), compared to mentors in other types of relationships. First, the nature of their communication was primarily one-way - the mentors gave advice and then observed whether their protégés followed up. The degree of protégé action then influenced the mentor's level of trust: "She took my advice and followed up", said one; another stated that he felt "there was a lack of initiative on the protégé's part...it certainly affected trust..."; and a third described that "she had to work with me; I told her she had to be open and ready to listen to move forward".

Perhaps due to the male mentors' pragmatic focus on career, the development of trust seemed to be somewhat superficial, (or it was not perceived to be necessary). As one mentor asked, "why would I need trust?" ; and he later pointed out, "there was enough trust". Another indication of the level of trust was the degree to which the mentors would take risks on their protégés' behalf. In at least two instances, the mentors said that their protégés were trustworthy enough that they would provide introductions for them, but they would not provide them with direct contact names. (Whereas making introductions requires a significant investment of time and a basic level of trust, the latter would involve greater personal risk and a deeper level of trust, as the mentor's reputation could be harmed by providing "carte blanche" with his business contacts).

\section{Female Mentor/Male Protégé:}

\section{- $\quad$ The Importance of the Interpersonal}

In contrast, when female mentors were asked "Do you feel that you developed trust in the relationship?" the majority of their responses were more definite, with emphasis on the affective, interpersonal side of the relationship. Three out of four reported affirmatively that trust had developed: "Yes, I felt very comfortable"; "Yes, I felt that from the beginning..."; "Yes, I think both of us, quite significantly, especially after the face to face". Note that two of the mentors used the word "feel". One, however, reported that she had experienced difficulties with the "match" and therefore was hampered in the development of trust (she then elaborated about the situation, explaining how her protégé had been frustrated with his personal situation). These findings suggest that women place more importance on the psychosocial elements of mentoring; and, in general, value the interpersonal aspects of relationship-building and emotional support in their relationships more than men. The former is consistent with Allen and Eby's (2004) findings in their survey research with 249 mentors: women reported providing more psychosocial support to all protégés, regardless of gender. It is also interesting to note that Allen and Eby hypothesized that, "the challenges inherent in cross-gender mentorships may be magnified in mentorships composed of female mentors and male protégés", but their findings were inconclusive (p. 131). 
- Two-way communication

Another finding was the emphasis on two-way communication and openness, which was not evident in the male mentors' comments. One mentor stated, "I was lucky that my protégé was fairly open, not resisting the process or my participation. And he seemed to be very respectful, as I was of his background". A second reported "I don't think that he was suspicious of anything I was asking him to do or any advice I was giving him; he was quite open... I was open with the advice that I gave him and that just continued".

\section{- $\quad$ Lack of Confidence}

Note the mentor's use of the words "resisting" and "suspicious" in these comments. These words indicate that the female mentors felt a lack of confidence in how the protégés would perceive them and the merit of their advice. This self-doubt is absent from the other mentors' comments. Given that female-male mentoring represents a reversal of traditional gender roles, this result is perhaps not unexpected. Women have typically been in positions with less power and control than men, and the role reversal may create some initial discomfort (Ragins and Sundstrom, 1989). As a result, this initial discomfort could influence the development of trust - female-male pairs could take longer to develop a deeper level of trust. It is also interesting to note, that of the 15 mentors overall, only one reported being "mismatched" - a female mentor with a male protégé in this group. Perhaps the non-traditional cross-gender matching contributed to this mentor's perceived lack of success.

\section{Mentors in Same Gender Relationships}

\section{Female Mentor/Female Protégé:}

\section{- Trust as a Growth Process}

Once again, there were no qualifiers when female mentors answered the first question, "Do you feel that you developed trust in the relationship?" All three were definite and positive about the development of trust in their relationships. As well, all three respondents emphasized the growth aspect of the relationship. They felt that they had immediately established trust and pointed out that it was a process - it "grew as we went along and is still growing". Their statements suggested that they wish to continue in these relationships: one mentor reported that "trust is continuing to grow, more like a friend now". According to Kram (1985), the "friendship" stage of mentoring is usually reached near the end of the relationship, which suggests that this mentor, at the very least, was able to establish a close relationship very quickly.

\section{- $\quad$ Empathic Communication}

Another predominant theme which emerged in further discussion with female mentors was the importance of communication and mutual understanding and feedback. The mentors expressed empathy in the protégés' situations and how they must be feeling. They also stressed the importance of establishing a comfortable rapport, to assist the protégé in expressing herself. As one mentor reported, "Sometimes she would come in, and I'd really have to pull it out of her, because I could sense something”. These findings support Ragins' (1997) theory that minority mentors strongly identify with minority protégés and therefore feel a strong sense of identification and generativity.

\section{- Communication over Career?}

Notably absent from these female mentors' discussion on trust was the topic of "career". In contrast to the male-female mentoring pairs, these female mentors did not use any language associated with profession, career, job, or employment when describing trust. The discussion focused entirely on interpersonal relationships and communication. This could be due to the fact that women perceive trust to be primarily associated with communication (as opposed to the instrumental aspects of a relationship). These female mentors' responses reflect Allen and Eby's (2004) findings that female-mentor-female-protégé relationships result in the greatest amount of psychosocial mentoring. They hypothesized that this could be due to the fact that women perceive that other women 
need the friendship and affirmation provided by mentoring more than men; or perhaps female mentors suspect that women are in greater need of psychosocial mentoring due to discrimination in the workplace.

Male Mentor/Male Protégé:

- $\quad$ Confident, Comfortable, and Conditional

The male mentors' responses were more affirmative than those provided by men involved in cross-gender mentoring relationships. When responding to the question about trust development in their relationship, their language was confident and clear-cut, without qualifiers. This could reflect their comparative comfort in this traditional malemale "business" relationship. However, that is not to say that the mentor's trust was unconditional - quite the opposite. There was a strong sentiment, expressed by all four mentors, that trust develops over time, that it was an exchange relationship, dependent upon favorable actions ("give and take"). As one mentor expressed, "I don't think that trust comes right from day one. You would be a fool. It's just not that way...". Another stated, "you need to earn trust"; and he went on to explain, "but to some degree it is predisposed, you have to trust each other to some degree to engage in partnership". (Here, he also suggests that trust may be a constant personality trait that some people possess.)

\section{- $\quad$ Tough Love}

There was a strong business tone throughout all of the responses, with an emphasis on career mentoring. The male mentors mentioned the importance of clear communication, but rather than emphasizing empathic listening and two-way feedback, (as the female mentors did), they stressed the importance of protégés accepting their advice, getting through "difficult" conversations, and "tough love". Two of the mentors described situations where they "tested" their protégés:

When I saw that my protégé was digressing - he wasn't focusing - things weren't going the way both of us wanted it to go, especially with time progress, etc., I had to say, "this is what we need to be doing - unless you don't trust me then you are free to do what you want...He understood that I was talking about his welfare...

One assignment - tough love - I suggested that he buy an egg timer and set it for 20 seconds and told him to have his answers fit into that time. He was very good at changing his style, making his answers more precise...

I'm still not entirely sure of his technical abilities and I've looked at different ways to test that. I think that the proof will be in the securities course. If he can pass the first time...

Progress towards a goal was key. The mentors seemed very aware of the 4 month target and the need to assist the protégés during that period. As one mentor expressed:

It was a case of OK, I have 4 months... what do I want to do in month 1, month 2, month 3, month 4. Let's agree, focus, and do it.

Overall, the male mentor's focus on career mentoring was consistent with the comments of male mentors in crossgender relationships as well. Theoretical perspectives such as social role theory would explain this finding: men are socialized to be career-oriented and success is measured by the degree of organizational ascendancy, power or financial rewards attained (Allen and Eby, 2004; Eagly and Crowley, 1986; Ragins and Sundstrom, 1989). Allen and Eby (2004) also found that men reported providing more career-related mentoring in their study of 249 mentors than women; but this was the first study from a mentors' perspective which has shown a significant difference. (Other research has focused on the protégé's perspective). 
Table 2: Initial Mentor Responses To Whether They Had Developed Trust

\begin{tabular}{|c|c|c|c|}
\hline \multicolumn{4}{|c|}{ Gender of Protégé } \\
\hline \multirow{3}{*}{$\begin{array}{l}\text { Gender } \\
\text { of } \\
\text { Mentor }\end{array}$} & & Female & Male \\
\hline & Female & $\begin{array}{l}\text { - "Yes, felt comfortable. Definitely.... Trust grew } \\
\text { as we went along and is still growing." } \\
\text { - Yes, definitely had trust... developed after a few } \\
\text { meetings..." } \\
\text { - Yes, the trust didn't happen the first day as she } \\
\text { was scared...trust is continuing to grow, more like } \\
\text { a friend now". }\end{array}$ & $\begin{array}{l}\text { - Yes, I felt very comfortable. } \\
\text { - Yes, I think both of us, quite significantly, } \\
\text { especially after the face to face. } \\
\text { - Yes. I felt that from the beginning actually. } \\
\text { - No, it wasn't a good match...there were a lot of } \\
\text { things....he had been here for } 2.5 \text { years and hasn't } \\
\text { had a job, so he is pretty disheartened and pretty } \\
\text { bitter... }\end{array}$ \\
\hline & Male & $\begin{array}{l}\text { - Yes, but why would I need trust? I am not } \\
\text { expecting to get anything from this...there was } \\
\text { enough trust... } \\
\text { - Yes, we had trust - I was pretty tough with her. } \\
\text { She took my advice and followed it...I never did } \\
\text { give her contact names... } \\
\text { - It certainly affected trust (referring to a lack of } \\
\text { follow up and initiative that he observed on the } \\
\text { protégé's part). } \\
\text { - Yes }\end{array}$ & $\begin{array}{l}\text { - Absolutely, yes. } \\
\text { - Yes. } \\
\text { - Yes, I think he trusts me. } \\
\text { - Trust is still growing. You need to earn trust, but } \\
\text { to some degree it is predisposed, you have to trust } \\
\text { each other to some degree to engage in } \\
\text { partnership. }\end{array}$ \\
\hline
\end{tabular}

\section{DISCUSSION}

This study explored the role of gender in mentoring relationships and how it influences the development of trust. Fifteen mentors were interviewed and their perceptions of trust were analyzed and compared. Our findings are consistent with Allen and Eby's (2004) results on mentoring functions which indicate that female mentors provide more psychosocial mentoring than do male mentors, who provide more career mentoring functions. They also resonate with theoretical perspectives such as social role theory, which suggests that women are socialized to provide more nurturing functions while men are taught to value organizational power and hence place more emphasis on career progression. How do these mentoring functions relate to trust? The interviewees' perceptions of trust were closely aligned to these functions. Women described trust in terms of communication and mutual understanding; they talked about the quality of their interpersonal interactions and how they related to the level of trust. Men, on the other hand, described trust in pragmatic, instrumental terms. They discussed trust in terms of the stated objective of the relationship, (career development and progress towards employment), and viewed the protégé as someone who needed to earn their trust through demonstrated action and by following up on commitments.

The results also indicate that both male mentors and female mentors were slightly less comfortable and confident in cross-gender relationships than those in same gender pairs. In their interviews, they spoke with less assurance about the development of trust. Females, for example, were concerned about their protégés' perceptions of their competence. Males, on the other hand, emphasized the "professional" nature of their relationships, suggesting that they may be concerned about others' perceptions. The former represents a reversal of traditional roles and this may explain the anxiety described by the female mentors; the latter may be indicative of male mentors' uneasiness regarding the possible sexual connotations of a cross-gender relationship - harassment and innuendo from others. Therefore, male mentors may simply find it safer to stick to "respectable" career mentoring. Furthermore, they may simply not be equipped with the skills to provide psychosocial mentoring.

\section{IMPLICATIONS FOR THEORY AND PRACTICE}

Although exploratory, this research has implications for practice. First, it suggests that the development of trust may differ between same sex and cross-sex mentoring pairs. For cross-gender mentoring, it may be more difficult to build trust, or it may simply take longer. Therefore, formal mentoring programs such as the Mentoring Partnership, (which has a minimum four-month commitment), should ensure that sufficient time is allocated for trust to be 
established. The mentors' responses indicated that, although trust was developing in most cases, it did not have time to develop to a higher level (few mentors cited examples whereby the level of trust changed throughout the duration of the relationship). The program coordinators could also, during the matching process, ask protégés and mentors whether they have a gender preference. Female mentors should be recruited for female protégés, whenever preferred and possible. Another input to the matching process should be the expectations of the protégé and the mentor. Protégés, for example, who are looking for psychosocial mentoring would be better matched with a female mentor whereas those with a strong and practical career focus might be better matched with a male. Another consideration is physical proximity. In the Mentoring Partnership program, location was a hindrance to several pairs, who mentioned that more face-to-face meetings would have enhanced the relationship (and the development of trust). Finally, setting clear parameters for the relationship would also help both partners understand their roles, establish a framework within which to operate, and thereby ensure that the foundation is set for the development of trust. This could help reduce role/gender ambiguity which seems to be inherent in cross-gender mentoring.

Several limitations of the study warrant discussion. First, the sample size was small. Because this was an exploratory study of gender differences and trust, this necessitated a qualitative design and smaller sample size. As a result, however, caution must be taken in making generalizations about this data, as it is exploratory in nature and context specific. Second, the sample was derived from a particular program - the Mentoring Partnership - at a particular point in time. It has specific characteristics and a context in which it operates. It is formal, non-work based, career focused, and designed for a particular purpose: to assist new Canadians in finding employment. A mediating factor in this program, as well, is the ethnicity of the participants. How does ethnicity interact with gender to influence trust? And finally, the duration of the program was another constraint. As mentioned above, four months may not be adequate, in many cases, to develop a trusting relationship. Although an initial level of trust may be established, it does not enable a deeper, more lasting relationship (e.g., Kram, 1985, found that most formal mentoring programs lasted 6-12 months and passed through four distinct stages).

This research also identifies a number of opportunities for further research. Based on these results, hypotheses could be generated and tested. For example, the development of trust appears to happen more rapidly and deeply with same gender pairs than cross-gender. Using a quantitative design, with a larger sample size, this phenomenon could be measured. Both mentors' and protégés' perspectives could be gathered through a questionnaire instrument, thereby examining quantitatively whether the results varied significantly. The element of time could also be introduced, by using a longitudinal design to measure trust at different intervals. This study followed the tradition of other mentoring research - it was retrospective and did not capture the time-sensitive nature of trust. But, as many of the participants noted, trust is something which is earned; it grows and develops over time. The research on trust suggests that initial trust is based on benevolence, integrity and competence. However, initial perceptions of trust are then revised based on risk-taking behaviors and consequences (e.g., see Mayer et al., 1995). Trust could thereby be tested at the beginning of a mentoring relationship and again later, to determine whether it had changed and why. By incorporating theoretical models of trust into research on mentoring, a richer, more complex view of mentoring, gender and trust could be examined.

\section{REFERENCES}

1. Allen, T.D., Day, R., and Lentz, E. (2005). The role of interpersonal comfort in mentoring relationships. Journal of Career Development, 31(3), 155-169.

2. Allen, T.D. and Eby, L.T. (2004). Factors related to mentor reports of mentoring functions provided: gender and relational characteristics. Sex Roles, 50 (1/2), 129-139.

3. Allen, T.D., Poteet, M.L., Eby, L.T., Lentz, E., and Lima, L. (2004). Career benefits associated with mentoring for protégés: A meta-analysis. Journal of Applied Psychology, 89(1), 127-136.

4. Allen, T.D. and Eby, L.T. (2002). Relationship effectiveness for mentors: Factors associated with learning and quality. Journal of Management, 29(4), 469-486.

5. Bowen, D.D. (1985). Were men meant to mentor women? Training and Development Journal, 39(2), 31-40.

6. Burke, R.J. (2002). Career development of managerial women. In Burke, R.J., Nelson, D.L. (Eds), Advancing women's careers: Research and practice. Oxford, UK: Blackwell. 32-46. 
7. Burke, R.J., and McKeen, C.A. (1990). Mentoring in organizations: Implications for women. Journal of Business Ethics, 9, 317-322.

8. Catalyst (2005). The Catalyst Census of Women Corporate Officers and Top Earners of Canada. Toronto, Canada: Catalyst, Inc.

9. Collins, N.W. (1983). Professional Women and their Mentors. Englewood Cliffs, NJ: Prentice-Hall.

10. Cooper, C.L. and Hingley, P. (1983). The Change-Makers, London, UK: Harper and Row.

11. Deaux, K. and Emswiller, T. (1974). Explanation of successful performance on sex-linked tasks: What is skill for the male is luck for the female. Journal of Personality and Social Psychology, 29, 80-85.

12. Eagly, A. H. and Crowley, M. (1986). Gender and helping behavior: A meta-analytic review of the social psychological literature. Psychological Bulletin, 100, 283-308.

13. Equal Opportunity Employment Commission. (2004). Glass ceilings: The status of women as officials and managers in the private sector. Washington, D.C.: Office of Research, Information and Planning.

14. Feldman, D. C. (1999). Toxic mentors or toxic protégés? A critical re-examination of dysfunctional mentoring. Human Resource Management Review, 9, 247-278.

15. Fitt, L.W., and Newton, D.A. (1981). When the mentor is a man and the protégé is a woman. Harvard Business Review, 59, 56-60.

16. Geertz, C. (1973). Thick description: Toward an interpretive theory of culture. In The Interpretation of cultures; selected essays. New York: Basic Books.

17. Headlam-Wells, J. (2004). E-mentoring for aspiring women managers. Women in Management Review, 19(4), 212-218.

18. Hurley, A.E. (1996). Challenges in cross-gender mentoring relationship: Psychological, intimacy, myths, rumors, innuendoes and sexual harassment. Leadership and Organization, 17(3), 42-50.

19. Jacobs, S. (1999). Trends in women's career patterns and in sex occupational mobility in Britain. Sex, Work and Organizations, 6(1),

20. Kram, K.E. (1983). Phases of the mentor relationship. Academy of Management Journal, 26, 608-625.

21. 37-44.

22. Kram, K.E. (1985). Mentoring at work: Developmental relationships in organizational life. Gleview, IL: Scott Foresman.

23. Leck, J.D. (2002). Making Employment Equity Programs work for women. Canadian Public Policy, 28, 85-100.

24. Lineham, M. and Walsh, J.S. (1999). Mentoring relationships and the female managerial career. Career Development International, 4(7), 348-352.

25. Lunding, F.J., Clements, G.L., and Perkins, D.S. (1978). Everyone who makes it has a mentor. Harvard Business Review, 56(4), 89-101.

26. Macoby, E.E. (1990). Gender and relationships: A developmental account. American Psychologist, 45, 513520.

27. Mayer, R.C., Davis, J.H., and Schoorman, F.D. (1995). An integrative model of trust formation. Academy of Management Review, 20(3), 709-734.

28. McAllister, D. J. (1995). Affect- and cognition-based trust as foundations for interpersonal cooperation in organizations. Academy of Management Journal, 38, 24-59.

29. Merriam, S. B. and Associates (2002). Qualitative Research in Practice. San Francisco, CA: Jossey Bass

30. Noe, R.A. (1988). Women and mentoring: A review and research agenda. Academy of Management Review, 13, 65-68.

31. Ragins, B.R. (1989). Barriers to mentoring: The female manager's dilemma. Human Relations, 42(1), 1-22.

32. Ragins, B.R. (1996). Jumping the hurdles: Barriers to mentoring women in organizations. Leadership and Organization Development, 17(3), 37-44.

33. Ragins, B.R. and Cotton, J.L. (1999). Mentor functions and outcomes: A comparison of men and women in formal and informal mentoring relationships. Journal of Applied Psychology, 84(4), 529-550.

34. Ragins, B.R. and McFarlin, D.B. (1990). Perceptions of mentor roles in cross-gender mentoring relationships. Journal of Vocational Behavior, 37, 321-339.

35. Ragins, B.R. and Sundstrom, E. (1989). Gender and power in organizations: A longitudinal perspective. Psychological Bulletin, 105, 51-88. 
36. Scandura, T.A. and Williams, E.A. (2001). An investigation of the moderating effects of gender on the relationships between mentoring initiation and protégé perceptions of mentoring functions. Journal of Vocational Behavior, 59, 342-363.

37. Schein, V.E., Mueller, R., Lituchy, T., and Liu, J. (1996). Think manager - think male: A global phenomenon? Journal of Organizational Behavior, 17, 33-41.

38. Thomas, D. (1990). The impact of race on managers' experiences of development relationship (mentoring and sponsorship): An intra-organizational study. Journal of Organizational Behavior, 11, 479-492.

39. Whitely, W., Dougherty, D.W., and Dreher, G.F. (1991). Relationship of career mentoring and socioeconomic origin to managers' and professionals' early career progress. Academy of Management Journal, 34, 331-351.

40. Wrightsman, L.S. (1991). Interpersonal trust and attitudes towards human nature. In Robinson, J.P., Shaver, P.R., Wrightsman, L.S. (Eds), Measures of Personality and Social Psychological Attitudes, 1, Academic Press: San Diego, CA. 


\section{NOTES}

